\title{
O xale, de David Mamet
}

Eduardo Freitas de Souza

A peça The shawl, de David Mamet, foi encenada pela primeira vez em 19 de abril de 1985, pela Goodman Theatre's New Theatre Company, em Chicago, no Briar Street Theatre.

A peça nos impressionou, como todo o resto da obra do autor, pela criatividade do enredo, pelas suas reviravoltas e, é claro, pela vivacidade dos diálogos, que são ágeis, concisos, rápidos e certeiros, os condutores diretos da trama, constituindo-se no desafio maior dos tradutores de Mamet.

Muito já se disse sobre o ouvido de Mamet para o diálogo, para a língua efetivamente falada nos EUA, o que criou a expressão Mametian e uma série de imitadores. No livro Writing in Restaurants ("Escrevendo em restaurantes"), o próprio Mamet critica essa tendência sua (e de seus seguidores) de escrever diálogos brilhantes e omitir parte da narrativa, no melhor estilo Ernest Hemingway e Harold Pinter, em que o não dito é tão ou mais importante do que aquilo que é efetivamente dito, assim atiçando a imaginação do leitor/plateia/audiência.

$\mathrm{O}$ trecho apresentado a seguir pretende reproduzir em língua portuguesa um pouco da eloquência desse autor, da agilidade de seus diálogos que levam da apresentação das personagens à colocação de parte do "problema" da peça: no primeiro ato de $O$ xale, João (optamos por traduzir os nomes), um médium, recebe em sua nova 
empreitada comercial a primeira cliente, a Srta. A, uma mulher fragilizada pela recente perda da mãe e atormentada pela questão de questionar ou não o testamento, do qual é excluída.

Nesse primeiro ato já se percebe o talento de João para manipular seus clientes; percebe-se também parte de sua filosofia de trabalho ("É puro bom senso", dirá para seu sócio mais adiante), como também se nota de que maneira essa manipulação é, antes de tudo, linguística, dialógica: João utiliza-se de generalizações (coisas que diz acontecer à maioria das pessoas), bem como de lugares-comuns (como a influência da lua sobre a colheita), para passar a induzir a cliente, ganhar sua confiança e obter as informações de que se vale para melhor persuadi-la de seus poderes e capacidades mediúnicas - isso enquanto a faz crer que está "adivinhando" tudo. "E você provavelmente deseja que eu informe você. Não é verdade... Não está correto: adivinhar... está tudo bem. Predizer... você quer que eu demonstre o meu poder?", diz ele, enquanto a faz crer que sabe mais sobre sua própria vida do que ela mesma.

The shawl teve um renascimento em Londres em 2009. Michael Billington (2009), em sua crítica para The Guardian, disse que muito da força da peça deve-se à identificação subconsciente do escritor com o protagonista, que não consegue nem explicar nem entender a fonte de sua mágica. Segundo Billington, a peça funciona bem porque cria dúvidas e porque sugere que o golpista extrai seu poder da necessidade da vítima de ser ludibriada; além disso, ainda de acordo com o crítico, Mamet é mestre na técnica de criar um ritmo musical a partir das elipses da fala cotidiana, e esta peça funcionaria como uma maravilhosa metáfora para o próprio processo teatral.

Kate Basset (2009), escrevendo sobre a peça para The Independent, também concorda com esse caráter metaficcional do texto, alegando que o trabalho de um médium clarividente é muito similar ao das pessoas que fazem teatro, pois ao se inventar e contar histórias e simular situações, pode-se de súbito parecer eletrizantemente convincente, como se tomado pelo espírito de outra pessoa. 
Sam Marlowe (2009), em sua resenha para The Times, diz que a peça levanta questões de fé que, com a desconfortável coexistência do secular e do espiritual neste século 21, mostram-se ainda muito pertinentes. Ainda segundo Marlowe, a peça explicita a prontidão com que nos entregamos a certezas confortadoras, mas dúbias, certezas essas que são tão poderosas e potencialmente perigosas quanto dinamite em um mundo em que o racionalismo, o fundamentalismo e o deus do consumismo, que a tudo devora, competem de maneira tão exacerbada.

A tentativa aqui é de transpor para a língua portuguesa esse diálogo vivo, real, ágil e conciso que é característica essencial da obra desse dramaturgo. 
Eduardo Freitas de Souza. O xale, de David Mamet

\section{The Shawl}

\section{The characters}

John: A man in his fifties

Miss A: A woman in her late thirties

Charles: A man in his thirties

\section{Act One}

\section{John and Miss A}

John: ... You see:

Miss A: I don't know...

John: Well, there is a rhythm in our lives, and at each point, at each point each of us should be doing that thing which corresponds to this rhythm. (Pause.) When you awaken it is to be brusque, to... to be hungry (pause), to cleanse your mind for new impressions. (Pause.) To be acquisitive. At night it is appropriate to think, to meditate. And so it is with your life. (Pause.) You have a problem. What does this mean? In your life, in your day, in your... as each one has his rhythm... you... and so you do. For we look at the stars. As they did. What do we see? We see this: that they named the constellations on their knowledge of the traits which appear in that...

Miss A: In...?

John: In that period. You see? It was the period that they observed. How the moon... (Pause.) How the moon, for example... influences us. Influences planting, reaping. How in our lives we are influenced. At one time in your life. At most times, perhaps, you would, you would not be here. Would you? (Pause.)

Miss A: No. 
John: No. Of course not. So we say, what is it that troubles you? And that you probably desire that I inform you. Is this not so?

(Pause.)

Yes?

Miss A: I don't understand.

John: I think you do. You've come to me for help. You wish me to resolve your "problem." First, though, you would like me to inform you what that problem is.

Miss A: I...

John: Is that not correct - to surmise... it's alright... to "guess"... you want me to exhibit my power. Is this not the truth? Is this not so? It is so. You wish me to, in effect, "read your mind." (Pause.) For the question is: WHAT POWERS EXIST? And what powers DO exist? And what looks after us? And... do you see? This is a rational concern. Is there an order in the world. And... you ask... and can things be known. Can things be known. (Pause.) And, of course, they can.

Miss A: ...they can.

John: Of course they can, as you have suspected. (Pause.) Have you not?

Miss A: Have I suspected it...?

John: Yes. And you have. For I see that you have... you have some psychic ability.

Miss A: I do...

John: And you have felt it. Yes. You have. Questioned it. But felt it. Said it was... Answer me, now... You said it was... you said it was...? Have one moment's faith. Answer me. You said it was...? 
Miss A: Coincidence.

John: Exactly. But it was not. When you felt it. In those instances you know that I refer to. And you know the power of which I speak. (Pause.) Don't you. (Pause.) Don't you?

Miss A: Yes.

John: I know you do. And it is real. As we know it is real. And why should we be frightened? To know...? And it is better to know. (Pause.) For we say "knowledge," what is it? It is our attempt to be part of something which continues. Which we are part of. And fear - what is it? We fear that thing that we wish does not exist. But we know it exists. Don't we? (Pause.)

Miss A: I don't know.

John: Yes, you do. For what has brought you here? That knowledge. That there is a hidden order in the world. And once you dreamed this. You... you sat and dreamed this meeting with me. Long ago.

Miss A: I did...

John: Dreamed this when you were young... isn't that so? Isn't that so - long ago. Dreamt that you would one day sit with me. Didn't you? (Pause.)

Miss A: Yes.

John: I know that you did. In summer. When you were a little girl. Late summer. Sitting on a - what is it? By... is it by the water...?

Miss A: Yes.

John: It is. Where is this?

Miss A: At...

John: At your home. Is it not? At your summer... 
Miss A: (simultaneously with "summer"): Yes. Our summer home.

John: I see... you by a tree. An oak? You sat and dreamed this meeting.

Miss A: Yes.

John: And I see another time of psychic power. When, you might have said "suspicion"... A suspicion warned you of a catastrophe. Is that correct?

(Pause.)

Miss A: Yes.

John: I see that it is. And you were right, is this not...?

Miss A: Yes. I was.

John: And I see other danger... and I see... (Pause.) When you were young. Blood. When you were quite young. A fall. And you bear the scar still. Twice in your life you have been near death. Once that you knew of, once that you did not. Now think of the times I am speaking of. (Pause.) Danger. When you were in grave danger. And you will remember what I mean, no, there is nothing to be frightened of. What is it? Please?

Miss A: You said "a scar."

John: That is correct. That is another time. A fall. But now: think back to... a time of physical danger.

Miss A: A... I don't... (Pause.)

John: Yes? (Pause.) What?

Miss A: Where is this scar?

John: It's on your left knee. What is it? (Pause.) 
Miss A: Oh...

John: Yes?

Miss A: I don't have a scar there. (Pause.)

John: You are quite wrong. And I see that you have forgotten it. As it is small. Now: if you would - if you would... if you would look now you would see that scar. Would you like me to turn away?

Miss A: I don't.

John (simultaneously with "don't"): It' alright. As I see it's important to you. You want to say you don't mean to "test" me... But you must trust me. And I am going to turn away. You look, and you'll see the scar.

Miss A: It's alright. I don't have to see the... I believe...

John (simultaneously with "believe"): No. You must look. Not belief but truth. Truth. For it is there. And that answers your doubts.

Miss A: I don't have a scar there.

John: Then you will prove me wrong, and then you'll know. Isn't it better to know? (Pause.) A small scar on your left...

Miss A: Oh.

John: I'm sorry? (Pause.) I'm sorry.

Miss A: I don't. I don't know what to say.

John: ...what to say... Tell me what you saw.

Miss A: There is a scar. I have a scar on my knee.

John: Yes. 
Miss A: I never knew it was there.

John (simultaneously with "was"): Yes. A small scar. You were quite young. When you were small then it was large. And it was traumatic, and so you repress it. We repress so much. But it all casts its shadow, and the things you would know are all in you and all... available to you. (Pause.) Now: I see a loss. And I see suffering in your life. I see a loss. I... either you or someone close to you has suffered a tragedy.

Miss A (softly): Yes.

John: Please...?

Miss A: Yes.

John: Recently.

Miss A: Yes. The loss of my...

John: Of your mother. Yes. (Pause.)

Miss A: You see that?

John: Wait a moment, now...

Miss A: I... you see that?

John: Please. Try to... just... try to relax your...

Miss A (simultaneously with "your"): My mother.

John: I know that you loved her very much. Don't speak. And I see, further... (Pause.) I see... we were speaking: of that time in summer. We were speaking. She was near you then. No. She was in the house. You. You sat by the water. That time that you dreamed this. She was nearby. It's alright. I promise you. You are safe now, no harm can come to you here. She was near to you that time that you dreamed this meeting. 
Miss A: Yes.

John: And she came out and she smiled. Now (Miss A starts to cry.) it's alright. (Pause.) It's alright. It's good. For you must mourn her... For she is very much with us now.

Miss A: My...

John: Yes.

Miss A: My mother... you see her?

John: I see her as she was, I sense her through you. Your... images... feelings... I see that time...

Miss A: What does she look like?

John (simultaneously with "like"): And I see a question in your mind. Which you will not phrase, and that question is - listen to me for I am going to answer it; that question is this - and you must not feel foolish; that question is: (pause) can one contact her? Can she be contacted. (Pause.) Although that is not the thing that has brought you here. But it arises. Can one raise the dead. (Pause.) Now, do you wish to know that? (Pause.) Answer me.

Miss A: Yes.

John: Yes. I know. For I see how many times in the day you have thought of her. Longed for her... Moments in childhood which have returned... loneliness... (Pause.) In your deep grief. And the questions of the spirit rise. And troubled, you come here. And we will lift your problems. And answer your doubts. As all is open. (Pause.) I would like you to come back tomorrow. And bring me a photograph of her. And now (for the time is not right for that other question) let us address that which brings you here today. In the midst of your grief. Where everything... where so much, as we see, is pain. And I see you've had much sorrow in your life. And yet... and I see strength... and you have borne through it. 
Miss A: I have...

John (simultaneously with "I"): You were going to say "you have attempted to," but you have... and you have survived. Your father...

Miss A: Died when I was...

John: And now you bear up beneath this double burden. And an active trouble comes to you. A question rises. Which has led you here. (Pause.) It concerns money. Is this not...? (Pause.) Is this not?

Miss A: Yes. How do you know?

John (simultaneously with "know"): And I see a matter of law. A legal...

Miss A: My...

John: It is your mother's will.

Miss A: Oh, my god.

John: Is this not...? (Pause.)

Miss A: Yes.

John: And you have come to ask me. If you should contest the will.

Miss A: How do you know that?

John: I... (Pause.) I... (Pause.) You must... (Pause.) Let us continue: 
Eduardo Freitas de Souza. O xale, de David Mamet

\section{O Xale}

\section{Personagens}

João: Um homem de cinquenta e poucos anos.

Srta A: Uma mulher com menos de quarenta anos.

Carlos: Um homem com trinta e poucos anos.

\section{Primeiro Ato:}

\section{João e Srta A.}

João: ...Você está vendo:

Srta. A: Eu não sei.

João: Bom, tem um ritmo em nossas vidas, e a cada momento, a cada ponto cada um de nós devia estar fazendo aquela coisa que corresponde a esse ritmo. (Pausa.) Quando a gente acorda é para ser brusco... estar com fome (pausa), limpar a mente para novas impressões. (Pausa.) Ser aquisitivo. À noite é apropriado pensar, meditar. E assim é com a sua vida. (Pausa.) Você tem um problema. O que isso quer dizer? Na sua vida, no seu dia, no se... como cada pessoa tem o seu ritmo... você... e então você age. Porque nós olhamos para as estrelas. Como eles faziam. O que nós vemos? Nós vemos isto: que eles nomearam constelações baseados no conhecimento dos traços que aparecem naquele...

Srta. A: Naquele...?

João: Naquele período. Você está vendo? Foi o período que eles observaram. Como a lua... (Pausa.) Como a lua, por exemplo... nos influencia. Influencia o plantio, a colheita. Como em nossas vidas nós somos influenciados. A uma certa altura da sua vida. Em geral, talvez, você não... você não viria aqui. Viria? (Pausa.) 
Srta. A: Não.

João: Não. É claro que não. Então nós dizemos: o que está incomodando você? E que você provavelmente deseja que eu informe você. Não é verdade?

(Pausa.)

Srta. A: Eu não estou entendendo.

João: Eu acho que você está. Você veio aqui me pedir ajuda. Você deseja que eu resolva o seu "problema". Mas, antes, você quer que eu lhe informe que problema é esse.

Srta A: Eu...

João: Não está correto: decifrar... está tudo bem... "adivinhar"... você quer que eu demonstre o meu poder. Não é verdade? Não é isso? É, sim. Você quer que eu, na verdade, "leia a sua mente". (Pausa.) Porque a pergunta é: QUE PODERES EXISTEM? E que poderes existem MESMO? O que é que cuida de nós? E... você está vendo? É uma preocupação racional. Existe uma ordem no mundo? E... você pergunta... pode-se saber as coisas? Alguém pode saber as coisas? (Pausa.) E, é claro, se pode.

Srta A: ...se pode.

João: É claro que se pode, como você tinha suspeitado. (Pausa.) Não tinha?

Srta. A: Eu tinha suspeitado...?

João: Tinha. E você tem. Porque eu sei que você tem... você tem uma habilidade mediúnica.

Srta. A: Eu tenho... 
João: E você já sentiu isso. É. Sentiu. Questionou. Mas sentiu. Disse que era... Me responda, agora... Você disse que era... você disse que era...? Tenha um momento de fé. Me responda. Você disse que era...?

Srta. A: Coincidência.

João: Exatamente. Mas não era. Quando você sentiu isso. Nessas ocasiões a que você sabe que estou me referindo. E você sabe do poder de que eu estou falando. (Pausa.) Não sabe? (Pausa.) Não sabe?

Srta. A: Sei.

João: Eu sei que você sabe. E é real. Como nós sabemos que é real. E por que nós devíamos ficar com medo? Saber...? E é melhor saber. (Pausa.) Porque se diz "saber", o que é isso? É a nossa tentativa de fazer parte de algo que continua. Do qual nós somos parte. E de que nós temos medo: o que é isso? Nós temos medo de que essa coisa que nós desejamos não exista. Mas nós sabemos que existe. Não sabemos? (Pausa.)

Srta. A: Eu não sei.

João: Sim, você sabe. Porque o que foi que trouxe você aqui? Esse conhecimento. De que existe uma ordem oculta no mundo. E uma vez você sonhou com isso. Você... você sentou e sonhou esse encontro comigo. Há muito tempo.

Srta A: Eu sonh...

João: Sonhou com isso quando era criança... não é verdade? Não é verdade: muito tempo atrás. Sonhou que um dia ia sentar aqui comigo. Não sonhou? (Pausa.)

Srta A: Sonhei.

João: Eu sei que você sonhou. No verão. Quanto você era uma garotinha. No final do verão. Sentada em um... O que é isso? Perto... é perto da água? 
Srta. A: É.

João: É. Onde é isso?

Srta A: Na...

João: Na sua casa. Não é? Na sua casa de vera...

Srta. A: (simultaneamente com "vera...") É. Na nossa casa de veraneio.

João: Eu estou vendo... você perto de uma árvore. Um carvalho? Você sentou e sonhou esse encontro.

Srta. A: Sonhei.

João: E eu vejo outra ocasião de poder mediúnico. Uma vez, você pode ter dito "suspeita"... Uma suspeita alertou você sobre uma catástrofe. Está correto?

(Pausa.)

Srta. A: Está.

João: Eu estou vendo que sim. E você estava certa, não estava...?

Srta. A: É. Eu estava.

João: E eu estou vendo outro perigo... e eu estou vendo... (Pausa.) Quando você era criança. Sangue. Quando você era bem pequena. Um tombo. E você ainda tem a cicatriz. Duas vezes na vida você esteve perto da morte. Uma vez você sabia; na outra vez, não. Agora pense nessas ocasiões de que estou falando. (Pausa.) Perigo. Quando você esteve em grande perigo. E você vai lembrar do que eu estou querendo dizer, não, não tem que ficar com medo de nada. O que é? Pode dizer.

Srta. A: Você falou "uma cicatriz". 
João: Correto. Isso foi outra vez. Um tombo. Mas agora: pense lá atrás em... uma situação de perigo físico.

Srta A: Uma... eu não... (Pausa.)

João: Sim? (Pausa.) O quê?

Srta. A: Onde é essa cicatriz?

João: É no seu joelho esquerdo. O que foi? (Pausa.)

Srta. A: Ah...

João: Sim?

Srta. A: Eu não tenho uma cicatriz no joelho esquerdo. (Pausa.)

João: Você está muito enganada. E eu estou vendo que você esqueceu. Como ela é pequena. Agora: se você puder... se você puder... se você puder dar uma olhada agora, você vai ver essa cicatriz. Você quer que eu me vire?

Srta. A: Não precisa.

João (simultaneamente com "não"): Está tudo bem. Como eu estou vendo que é importante para você. Você está querendo dizer que não está tentando me "testar"... Mas você tem que confiar em mim. E eu vou me virar. Você olha, e você vai ver a cicatriz.

Srta. A: Tudo bem. Eu não tenho que ver a... Eu acredito...

João (simultaneamente com "acredito"): Não. Você tem que olhar. Não se trata de acreditar, se trata da verdade. A verdade. Porque ela está lá. E isso responde às suas dúvidas.

Srta. A: Eu não tenho cicatriz nenhuma no joelho. 
João: Então você vai provar que eu estou errado, e então você vai saber. Não é melhor saber? (Pausa.) Uma pequena cicatriz no seu joelho esquerdo...

Srta. A: Ah.

João: O que foi? (Pausa.) O quê que foi?

Srta. A: Eu não. Eu não sei o que dizer.

João: ...o que dizer... Me diga o que você viu.

Srta. A: Tem uma cicatriz. Eu tenho uma cicatriz no joelho.

João: Tem.

Srta. A: Eu nunca soube que tinha.

João (simultaneamente com “tinha"): É. Uma cicatriz pequena. Você era muito novinha. Quando você era pequena, então a cicatriz era grande. E foi traumático, e então você reprimiu. Nós reprimimos tanta coisa. Mas tudo deixa a sua sombra, e as coisas que você sabia estão todas em você e todas... acessíveis a você. (Pausa.) Agora: eu estou vendou uma perda. E eu estou vendo sofrimento na sua vida. E eu estou vendo uma perda. Eu... ou você ou alguém próximo a você sofreu uma tragédia.

Srta. A (suavemente): Sim.

João: Por favor...?

Srta. A: Sim.

João: Recentemente.

Srta. A: Sim. A perda da minha... 
João: Da sua mãe. Sim. (Pausa.)

Srta. A: Você está vendo isso?

João: Espere um instante, agora...

Srta. A: Eu... você está vendo isso...?

João: Por favor. Tente... somente... tente relaxar sua...

Srta. A (simultaneamente com "sua"): A minha mãe.

João: Eu sei que você a amava muito. Não diga nada. E eu estou vendo, mais adiante... (Pausa.) Eu estou vendo... nós estávamos falando: daquela vez no verão. Nós estávamos falando. Ela estava perto de você aquela vez. Não. Ela estava dentro de casa. Você. Você estava sentada perto da água. Aquela vez em que você sonhou com esse encontro. Ela estava por perto. Está tudo bem. Eu lhe juro. Você está a salvo agora. Nada de ruim pode lhe acontecer aqui. Ela estava perto de você aquela vez que você sonhou com esse encontro.

Srta. A: Estava.

João: E ela saiu da casa e sorriu. Agora (a Srta. A começa a chorar) está tudo bem. (Pausa.) Está tudo bem. Está bom. Pois você tem que ficar de luto por ela... Porque ela está muito conosco agora.

Srta. A: A minha...

João: $\operatorname{Sim}$.

Srta. A: A minha mãe... você está vendo ela?

João: Eu estou vendo ela como ela era. Eu a sinto por intermédio de você. As suas... imagens... os sentimentos... Eu estou vendo aquela vez... 
Srta. A: Qual é a aparência dela?

João (simultaneamente com "dela"): E eu vejo uma pergunta na sua cabeça. Que você não vai formular, e essa pergunta é (me escute porque eu vou responder, a pergunta que é), e você não deve se sentir tola; essa pergunta é: (pausa) dá para entrar em contato com ela? Pode-se fazer contato com ela? (Pausa.) Embora não tenha sido isso que trouxe você aqui. Mas isso está surgindo. Pode-se levantar os mortos? (Pausa.) Agora; você quer saber isso? (Pausa.) Me responda.

Srta. A: Quero.

João: É. Eu sei. Porque eu vejo quantas vezes no dia você pensou nela. A saudade que você sente dela... Momentos da infância que retornaram... solidão... (Pausa.) Na sua mais profunda dor. E levantam-se as questões do espírito. E incomodada, você vem aqui. E nós vamos extinguir os seus problemas. E responder às suas dúvidas. Pois está tudo aberto. (Pausa.) Eu gostaria que você voltasse amanhã. E me trouxesse uma fotografia dela. E agora (porque não é a hora certa pra aquela outra pergunta), vamos nos concentrar no que trouxe você aqui hoje. Em meio a sua dor. Em que tudo... em que tanto, como nós estamos vendo, é dor. E eu estou vendo quanta tristeza você teve na vida. E ainda assim... e eu vejo força... e você suportou isso tudo.

Srta. A: Eu suportei...

João (simultaneamente com "suportei"): Você ia dizer que "você tentou", mas que você... e que você sobreviveu. O seu pai...

Srta. A: Morreu quando eu tinha...

João: E agora você tem que carregar essa carga dupla. E lhe aparece um problema concreto. Surge uma questão. Que foi o que trouxe você aqui. (Pausa.) Tem a ver com dinheiro. Não é mesmo...? (Pausa.) Não é?

Srta. A: Tem. Como que você sabe? 
João (simultaneamente com "sabe"): E eu estou vendo um assunto legal. Uma questão jurídica...

Srta. A: A minha...

João: É o testamento da sua mãe.

Srta. A: Ah, meu Deus.

João: Não é isso...? (Pausa.)

Srta. A: É.

João: E você veio me perguntar. Se você deve contestar o testamento.

Srta. A: Como que você sabe isso?

João: Eu... (Pausa.) Eu... (Pausa.) Você tem que... (Pausa.) Vamos continuar:

\section{Referências}

BASSET, Kate. The Shawl, Arcola, em resenha para The Independent, 2009. Disponível em: <http://www.independent.co.uk/arts-entertainment/ theatre-dance/reviews/the-shawl-arcola-londonbrpunk-rock-lyrichammersmith-londonbrkatrina-bargehouse-london-1786337.html> Acesso em 10 maio 2010.

BILLINGTON, Michael. The Shawl, em resenha para The Guardian, 2009. Disponível em: <http://www.guardian.co.uk/stage/2009/sep/17/the-shawldavid-mamet> Acesso em 10 maio 2010.

MAMET, David. The Shawl. New York: Grove Press, 1985.

MARLOWE, Sam. The Shawl at the Arcola, em resenha para The Times, 2009. Disponível em: <http://entertainment.timesonline.co.uk/tol/ arts_and_entertainment/stage/theatre/article6835558.ece> Acesso em 10 maio 2010. 